\title{
Preface
}

\section{Mesozoic and Cenozoic Crustacea: updating their systematics}

\author{
Francisco J. Vega ${ }^{1, *}$, Alessandro Garassino ${ }^{2}$ \\ ${ }^{1}$ Instituto de Geología, Universidad Nacional Autónoma de México. Ciudad Universitaria, 04510 Coyoacán, México, D. F. \\ ${ }^{2}$ Museo di Storia Naturale, Sezione di Paleontologia, Corso Venezia 55, I-20121 Milano, Italia. \\ *vegver@unam.mx
}

The study of fossil crustaceans has become more active during recent years, including contributions from countries where this kind of fossils were practically unknown. New techniques to study the detailed morphological features have also been developed by some researchers. Systematic paleontology is the foundation to understand the evolution, phylogeny and paleoecology of many crustacean groups. Report of new species is not only important to know the paleodiversity of certain group, it can also contribute to know the biostratigraphic and paleobiogeographic range of higher taxa that were previously thought to be distributed in restricted regions. Style of preservation may affect the shape and features of fossil species, and the complete knowledge of the morphology trough systematic description may be an important tool to recognize and differentiate new species.

Several new taxa are described, as well as new occurrences of previously known species, from primitive to advanced brachyurans. Part of the diverse and representative fossil record of decapods from Italy is presented, as well as crustaceans from important localities from Spain, France and Germany. Samples of fossil crustaceans from Iran, Morocco and Mexico are also included.

This special volume includes 17 contributions on Jurassic to Pliocene localities from France, Spain, Italy, Germany, Morocco, USA, Mexico and Iran. A new family, genus and species are erected for portunoid crabs from the Eocene of Spain. From the Jurassic of France, a new species of homolodromid crab is reported. A new species of goneplacid crab is described from the Pliocene of Italy. New records of Pliocene crabs are also reported from the Pliocene of Reggio Emilia in Italy. The palobiogeographic range of Cenomanocarcinus vanstraeleni Stenzel, 1945, is extended to the Turonian of Morocco. An exceptionally wellpreserved specimen from the Miocene of France represents a new species of stomatopod. A review of the fossil species of Goneplax Leach, 1814 result in erection of a new genus and assignment of several species to different genera. A rich decapod fauna from the Early Pleistocene of Italy is reported. The first record of polychelid lobsters is recorded for the Jurassic of Germany. A record of an extant species of stomatopod is presented from the Pliocene of North Carolina, USA. Two ghost shrimp taxa from the Lower Maastrichtian Ocozocoautla Formation in Chiapas (Mexico) are recorded. The diverse Campanian-Maastrichtian crustacean fauna from Coahuila (NE Mexco) now includes a new species of homolid crab. Exceptionally preserved upogebiid specimens from the Eocene of California, USA are reported using innovative techniques for the study of fossils in plattenkalk deposits. A new brachyuran family is proposed to accommodate Montezumella Rathbun, 1930, previously assigned to Cheiragonidae Ortmann, 1893, based on well-preserved specimens from the Eocene of Catalonia. A new species of erymid lobster Enoploclytia tepeyacensis $\mathrm{n}$. sp., is reported from the early Campanian beds of the Austin Group in Coahuila (NE Mexico). Five species of crabs, including a new one, are reported from the Middle Miocene Guri Member of the Mishan Formation in southwestern Iran. A short note is included on a small shrimp from the famous Lagerstätten Tepexi de Rodríguez, Puebla, México.

We hope this volume will be useful and interesting to specialists and a wider audience, looking for more contributions to come, which will help in our understanding and knowledge of the crustacean evolution.

We would like to express our sincere gratitude to Denise Hernández Villalva, for her patience and professional work as technical editor of this special number. We also thank the rest of the technical edition team of the Boletín de la Sociedad Geológica Mexicana for their assistance and support: León F. Álvarez, Barbara Martiny, Juan Carlos García y Barragán, Aldo Ramos Rosique, Andrés Omassi, Andrew Boni, Mario De Leo Winkler, César Aguilar Ramírez, Olga María Ramírez Flores, Daniel David Díaz Contreras, and Miguel Cruz. 